\title{
Representations of Primary Care Professionals about the Occupational Risk of HIV Infection
}

Marina Celly Martins Ribeiro de Souza ${ }^{1}$

Maria Imaculada de Fátima Freitas ${ }^{2}$

This was a qualitative study, based on the Social Representations Theory, with professionals that work in primary care, about the risk of HIV infection to which they are exposed in their quotidian work routine. Twelve physicians and nurses who work in two Health Centers in the city of Belo Horizonte, MG, Brazil, were interviewed. The final analysis, carried out using the saturation of information criterion, was based on the method proposed by Structural Analysis of Narrative. The results show that the health professionals interviewed knew the infection risk in their work routine, representing it as very low in primary care, because they relate it to technological complexity which they consider does not exist in the level of assistance in which they work. They believed that the use of personal protection equipment may minimize the risks and that, nowadays, no primary care professional refuses to attend a patient due to fear of infection, even if not using all the recommended precautions.

Descriptors: Professional Practice; Medical Assistance; Nursing Care; Primary Health Care; AIDS Serodiagnosis.

\footnotetext{
${ }^{1}$ RN, M.Sc. in Nursing. E-mail: marinacelly.souza@gmail.com.

2 RN, Ph.D. in Health Education, Associate Professor II, Escola de Enfermagem, Universidade Federal de Minas Gerais, MG, Brazil. E-mail: peninha@enf.ufmg.br.
} 


\title{
Representações de profissionais da atenção primária sobre risco ocupacional de infecção pelo HIV
}

Este é um estudo qualitativo, fundamentado na Teoria das Representações Sociais, com profissionais que atuam na atenção primária, sobre o risco de infecção pelo HIV, ao qual estão expostos no cotidiano do trabalho. Foram entrevistados doze profissionais médicos e enfermeiras que atuam em dois centros de saúde no município de Belo Horizonte, MG, Brasil. A análise final se deu com a saturação das informações, pelo método proposto pela Análise Estrutural de Narração. Os resultados desvelaram que os profissionais de saúde entrevistados conhecem o risco de infecção em seu cotidiano de trabalho, representando-o como muito baixo na atenção básica, porque o relacionam à complexidade tecnológica, que consideram não existir no nível de assistência em que atuam. Acreditam que o uso de equipamentos de proteção individual pode minimizar os riscos e que, hoje, nenhum profissional da atenção básica deixa de atender pacientes por medo de se infectar, mesmo não utilizando todas as precauções recomendadas.

Descritores: Prática Profissional; Assistência Médica; Cuidados de Enfermagem; Atenção Primária à Saúde; Sorodiagnóstico da AIDS.

\section{Representaciones de profesionales de la atención primaria sobre riesgo ocupacional de infección por el virus HIV}

\begin{abstract}
Se trata de un estudio cualitativo, fundamentado en la Teoría de las Representaciones Sociales, con profesionales que actúan en la atención primaria sobre el riesgo de infección por el HIV a que están expuestos en su trabajo cotidiano. Fueron entrevistados doce profesionales, médicos y enfermeras, que actuaban en dos Centros de Salud en el municipio de Belo Horizonte, MG, Brasil. El análisis terminó con la saturación de las informaciones, por el método propuesto por el Análisis Estructural de Narración. Los resultados revelaron que los profesionales de la salud entrevistados conocen el riesgo de infección en su trabajo cotidiano, representándolo como muy bajo en la atención básica, porque lo relacionan con una complejidad tecnológica, que consideran no existir en el nivel de asistencia en que actúan. Creen que el uso de equipamientos de protección individual puede minimizar los riesgos y que, hoy, ningún profesional de la atención básica deja de atender pacientes por miedo de infectarse, inclusive no utilizando todas las precauciones recomendadas.
\end{abstract}

Descriptores: Práctica Profesional; Asistencia Médica; Atención de Enfermería; Atención Primaria de Salud; Serodiagnóstico del SIDA.

\section{Introduction}

Professionals in the health area are exposed to the same risks (chemical, physical and ergonomic) to which other workers are subjected, plus those represented by biological agents, since they may have daily contact with blood or other organic fluids. The emergence and reemergence of infectious diseases, especially when the mode of infection occurs by the penetration of contaminated, piercing or cutting objects, have brought new implications for professionals and for the organization of work in the health services. In the care of people infected by viruses, bacteria or other micro-organisms, the professional is exposed to occupational hazards, bringing ancient representations about transmissibility and epidemic diseases ${ }^{(1-2)}$.

With the discovery of the human immunodeficiency virus (HIV) and the elucidation of its mode of 
transmission, the State and the health institutions have reinforced the need for standards, monitoring and evaluation reports made by health surveillance, to reduce the consequences of accidents by occupational exposure to potentially infected organic fluids ${ }^{(3)}$. Parallel to the confirmation, by epidemiology, of the discovery of a new disease transmissible through sexual contact and, later, through other organic fluids, the first cases were reported of healthcare workers who acquired HIV as a result of their professional activity ${ }^{(4)}$. Society, on becoming aware of these findings, added representations of the disease to those existing, especially about contagion and epidemics, defining others concerning 'risk groups', for the sexual lifestyle and the culpability of the person who is infected, being considered by many as deviant behavior. This also contributed to the construction of stereotypes of the extreme thinness of the patient and the condemnation to a quick death, causing fear and prejudice, with silence and denials from society ${ }^{(5)}$. All these representations were also shared by professionals who bring them to their quotidian work life. However, since the epidemic began, new scientific knowledge has been accumulated, focused on prevention and treatment. Many representations have been questioned, but not necessarily changed with the same speed as the advancement of science ${ }^{(6)}$. Professionals have maintained a representation that the risk exists, but have always taken more care when knowing the HIV seropositivity of the patient ${ }^{(5)}$. Health professionals are the people who have faster access to scientific information, but they retain fears and representations of common sense that can interfere with the work process. Thirty years after the beginning of the epidemic, what changes have occurred, in the reconstruction and development of new representations by health professionals about the disease and the risks of HIV infection? How do primary health care service workers represent the risks of HIV infection?

The aim of this study was to analyze the representations of health professionals working in primary care about the risk of HIV infection that they are exposed to in their quotidian work.

\section{Method}

This was a qualitative study based on the theory of Social Representations( ${ }^{(7)}$, using the method of Structural Analysis of Narrative to perform the interpretation of the interviews ${ }^{(8)}$.

The study of representations allows the investigation of phenomena that often constitute major social problems, being used for their identification and interpretation, for understanding groups, cultures or societies that have appropriated them, in order to establish modes of conduct and give rise to interventions and evaluations ${ }^{(9)}$. Taking a representation as something that is established in a collective way, from exchanges and practices within a historical context, one can assume that the representation is responsible for supporting judgments and attitudes. Thus, it can be considered that, to the extent that social representations are responsible for giving meaning and coherence to the universe lived and are expressed in various forms of communication, they are configured as a backdrop for the attitudes of individuals ${ }^{(10)}$, and therefore also for the individual's

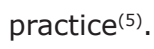

\section{Research subjects}

Professionals who worked in two health services that comprise the primary care of Belo Horizonte, Minas Gerais, participated in the survey and were interviewed between February and March 2008. A period of working at least six months in the services was considered to ensure that the interviewee had lived experiences on the subject of study. Interviewees were tertiary level health professionals, physicians and nurses, members of the Family Health Teams and of the support teams of the units.

The number of interviewees was not prior defined and resulted in twelve at the end. We used the criterion of saturation of the topics discussed by the participants to interrupt the collection. The interviews were performed in the working environment of participants, in an appropriate place in order to guarantee confidentiality and freedom. The interviews were recorded on tape and later transcribed, thus allowing the analysis of the speech of the subjects.

\section{Ethical considerations}

The study was approved by the Research Ethics Committee of the Municipal Council of Belo Horizonte and by the Research Ethics Committee of the Federal University of Minas Gerais.

The subjects were informed about the topic and the aims of the research and signed a free prior informed consent form as required by Resolution 196/96 of the National Health Council(11). Each was clearly informed that participation would be free and their eventual withdrawal respected, not causing any prejudice to their work, and that the source and the statements would be used confidentially in all materials produced. 


\section{Technique and Instrument for qualitative data collection and analysis}

The open and in depth interview was used, seeking greater flexibility, richer information and an image closer to the complexity of the situations or phenomena studied. The data were processed using the method proposed by the Structural Analysis of Narrative(8). This method is within Comprehensive Sociology, is inductiveanalytical and of reconstruction of the meanings, highlighting the subjectivity of the interviewees. The structural analysis was initiated by the vertical reading of each interview, seeking the understanding of the whole speech of each subject. Then horizontal analysis was performed, in which the interview was 'deconstructed' by the objects of the subjects' statements into sequences (S). These sequences were numbered $(\mathrm{S} 1, \mathrm{~S} 2, \mathrm{~S} 3, \ldots)$ and within each one, the facts (F), feelings, judgments and justifications presented about them (J), with the characters involved, people and institutions $(\mathrm{P})$, also marked.

Also at this stage, the sequences dealing with the same object were grouped, as were the 'justifications' about each and their respective characters, forming an 'empirical category' about that object of representation of the subject, which was then provisionally named. At the end of this stage, the detailed analysis of each interview was obtained, with the representations about each object narrated, with their conjunctions and disjunctions.

Finally, cross-sectional analysis was performed, comparing all the interviews, by their empirical categories, which were then named by the researchers, considering the representations encountered about the objects of the statements, according to the Theory of Social Representations. To finish the analysis, each category encountered was collated with the results of other studies from the literature, defining the theoretical categories of representations.

\section{Results and Discussion}

Seven female nurses (ENF) were interviewed and five physicians (MED), two male and three female. The age of the professionals varied from 27 to 60 and the time of performance in primary care ranged from six months to 13 years. Despite these major differences, those that had worked for longer in public health did not provide more specific, more elaborate or different representations than those of who had work for less time. It may also be noted that the different academic backgrounds (in this case, nursing and medicine) did not affect the representations encountered in the reports analyzed. Thus, regardless of professional category, there was homogeneity in the statements of all participants and it was not possible to conclude that any type of representation is related exclusively to a group as a result of specific vocational training. The representations encountered fell into the following categories: 1 ) risk and structure of the health service, 2 ) risk and knowledge of the serology of the client attended; 3 ) risk and legal standards of protection.

In the first, there is conformity among interviewees in recognition of the existence of the risk of HIV infection in the quotidian activities carried out in primary care:

The risk of HIV infection exists. It exists in technique, it exists technically (Enf 2).

So, a risk exists [of HIV infection] yes (Enf 1).

However, all relativize this risk, considering it of little importance:

But the risk [of HIV infection] in the primary level [of care] is very small, very small. We deal a lot with patients in the clinic and do not have so much risk ... (Med 3).

I think that it worries a little [the risk]. Thus, in a health center the risk is not high, it is a low risk (Med 4).

But here [in primary care] we do not have much [risk of infection], no (Med 5).

The subjective evaluation of risk made by interviewees was consistent with what studies say about this subject ${ }^{(12)}$, showing that the probability of health professionals acquiring HIV from patients is very small, especially if compared to other infectious diseases such as hepatitis. However, they represent the risk of actions performed in the health units as unimportant because they compare with the risk in the secondary and tertiary levels of health care that they consider greater:

In primary care, this [risk of HIV infection] is much smaller it is something that is not such a worry as, for example, in a hospital setting, or in invasive procedures, which never happen here ... (Med 1).

I don't see greater exposure [in primary care], but I do in the hospital. In a large hospital the individual does not say, the family is not present to inform us ... (Med 2).

In primary care specifically, I think there is very little risk of being contaminated by HIV, considering that primary care focuses on prevention, doesn't it? I mean, in tertiary care, specifically, it is more common (Enf 3).

From the analysis of these statements, a strong representation was defined, linked to the risk of becoming infected in the hospital environment, which is seen as 'the place of complex and depersonalized care' in which, 
often, the patients - as well as their families - cannot express themselves or keep their condition secret. The justifications point to a lack of evaluation and depth of understanding, because every patient is possibly infected and it will not be their declaration or that of their family that will protect the professional. Moreover, there is a representation that most activities performed in a health unit are related to prevention while in other levels of care, they are curative, forgetting that, also in these other services, prevention is in all actions. Those ideas organize the central one, found in the conjunction of the discourses of the professionals, that the risk is very high where 'there are many invasive procedures, especially in tertiary care'. This idea appears as a representation without any scientific basis, because health procedures, invasive or not, must be conducted with adequate protection for the worker and the patient, regardless of the level of attention. Thus, it can be affirmed that these representations are found outside the scientific origin of training of these professionals, since the risk is not related to the level of attention, but to the way of protecting themselves in any environments or health services.

The second category, risk and knowledge of the serology of the client, shows ambiguous representations, with references of common sense mixed with those from science, historically constructed and often very old. On one hand, there is some concern when the person is known to be infected with HIV, which can generate, in the professional, fear and even resistance to the monitoring and development of actions directed to that person ${ }^{(13)}$. MED 1 relativized his concern by denying that this is excessive, but affirmed its existence:

There is a risk, isn't there? But I think the risk is not so high, I think it is not so alarming to attend an HIV positive patient, even if we know beforehand. I'm not excessively concerned with it [risk of being infecting] and fear of attending an HIV patient, no.

But to so vehemently deny his fear, without being asked, MED 1 is pointing to the contrary. The representation is that the infected person is someone who brings the danger closer to him. The representations are of psychosocial order of the individual and collective life, the fear of HIV infection is referring to the fear of the AIDS epidemic, which in turn brings the very old metaphor of the pestilent death sweeping through the individual and population ${ }^{(14)}$. The assistance offered is facilitated, from the point of view of the interviewees, because if they are certain that the person is infected, they take all precautions not to get into the dreaded cycle of the contagion and epidemic. Scientific knowledge passes away, which points to the fragility of the professional training, with teaching methods based on deductive reasoning, centered on the transmission of information and leaving aside the reconstruction of representations. To understand these representations, recognize them as important and contribute in their re-elaboration would be more productive choices to reduce the fears, prejudices, and would certainly help in the changes for the solidification of one of the assumptions of the Brazilian Unified National Health System, which is that of integrality of care, in an equanimous and solidary way. Paradoxically, on the other hand, there are, in general, representations that any user of the health services may be infected, but it is quite peripheral in relation to the fact that professionals have a greater concern when they are know the patient to be HIV seropositive. They forget that seropositivity is not necessarily visible. However, the 'customs' are evolving. A study performed with dental surgeons ${ }^{(15)}$, found that the health professionals who, at the beginning of the discovery of AIDS, tended to refuse to attend people with HIV due to numerous factors such as their own ignorance about the disease and its forms of transmission, today, in most cases, have no resistance to assist them. That is because, according to the authors, these professionals seem to see the importance of using correct equipment for individual protection in health care assistance, even if they do not do so in every situation.

The Ministry of Health(16) determines protective measures for the work of professionals in the health area, in Regulation 1679 of September 19, 2002, covering the structuring of the National Network of Integral Health Care for Workers in the Unified National Health System. For nursing professionals, for example, the Regional Nursing Council of Minas Gerais, through Regulatory Standard 32, requires that professionals use Personal Protective Equipment (PPE) in activities that pose risk of contamination by any microorganisms. These regulations are necessary in light of the inherent and passive prevention risks during activities of health care.

When referring to legislation about protection and occupational risks, which was characterized as the third category constructed in the analysis, the representations are centered on the power conferred to the official standards. The former had been overlooked at the time of the discourse referring to the precaution standards which are represented as obligations to be followed. But they are not necessarily incorporated as a value for each 
of them, especially by someone other than the one who is narrating their practice. The existence of standards is valorized, but there is an area of reversibility in action that permits the subject to not keep to them, cheating a little in their daily lives. In this sense, it is emphasized that professionals recognize the existing legislation as critical to order the quotidian work, strengthening the need and importance of the use of PPE in the health services. They affirm that with the use of such equipment, the risk of HIV infection, considered small, becomes even smaller:

So, there is a risk, but since adopting the safety measures, this risk is greatly minimized. For example: Gloves alone do not protect you from needlestick accident, but they minimize it. If you have risk of fluid going in the eyes, wearing goggles is a good form of protection, isn't it? (Enf 1).

You have to prevent it, wearing gloves, using the PPE, proper equipment of PPE! So then, if we protect ourselves... we have to do our part, thus, using the protection equipment. (Enf 6).

We have to have at hand all the protective equipment during procedures, when necessary, in order not to contaminate, to not have a problem (Med 3).

In a first response about the issue, all interviewees say they take protective measures and deny that they themselves perform any invasive procedures, in which there is contact with bodily fluids, without the use of instruments for protection. In later responses, this is all relativized, as some affirm that not everyone does, even knowing what is necessary. ENF 7 and ENF 1, for example, speak of professionals whose positions increase the chances of exposure, due to non-use or improper use of PPE in the health units, but this does not include themselves. The representations of each one about themselves are of always strictly following the rules!

...So, I've seen a dentist attending without gloves; which is something very real: no use for us to say that the health professional is protecting themselves, because they are not, no! ... For example, I've seen an auxiliary puncturing a vein without gloves. But whenever I'm near I reinforce this, I guide, I do, because I cannot do anything without gloves, right? (Enf 7).

What happens, sometimes, is the lack of care of professionals in their own handling of sharps, why not use the protective equipment: goggles, gloves ... (Enf 1 ).

The practice of interviewees was not the object of direct observation in this study. The intention, here, was to listen to the representations and practices that they were willing to report. It is the view of each one on their practice and how they see it, not that this is exactly what happens in the quotidian life. Observational research methods and statistics have been used in other studies ${ }^{(12,17)}$ on the ways professionals protect themselves, with results that indicate a significant distance between what they say they should be doing and what they do in their quotidian work. Due to the routine, which leads to distraction and relaxation, the representation of the risk is small and, often, workers in the health area 'forget' what they know and do not protect themselves adequately. Moreover, it is worth asking whether, in the representations about the risk of HIV infection, another, more powerful representation is not included, with respect to the need for anyone to not be totally subordinated to the rules and to take some risk to prove stronger than everything. The sociology of risk suggests that every human being plays with fear, courage, life and death, to a lesser or greater degree, facing situations that, for some, would be unacceptable and, for them, signify a way of feeling alive and able to prove, especially to themselves, that they can beat death. The game would be not to die, but to live more intensely(18). Obviously, the work of physicians and nurses, or any other professional in the primary health care services, cannot be accommodated within these maximum limits, but it must be considered that, a little transgression, probably, also makes up part of their lives, found at the less radical pole of the options analyzed by sociological research. The 'zero risk', objectively, does not exist, as there seems to be no one who has 'zero' desire to transgress the rules, even though in a more or less unconscious way.

\section{Final considerations}

The representations concerning the risk of infection to which the professional is exposed in the quotidian of their work in primary care reveal the recognition, by the interviewees in this research, of a situation characterized as 'low risk', particularly if compared with other levels of care. However, one can apprehend an impoverished discourse, which shows little criticism because the other side would be 'high risk' which would be in secondary and tertiary care services that concentrate 'invasive procedures'. As a way of guaranteeing that the risk of infection remains minimal, the interviewees indicate the use of personal protective equipment. Each one says that they make use of PPE but that others do not. In fact, many professionals said, "how can I confess here, talking about protection, that I do something that I know is incorrect or, at least, not according to standards?" However, the 'other' that does can be anyone, including the narrator... 
Thus, the representations of the representations that others have of themselves can raise their self-esteem, but, can also lead them to negligence and to the lack of strength to accept changes.

In fact, the three categories of representations about the occupational risk of infection in primary care intertwine with what is established as the structure of services, the legal standards of protection and the knowledge/ignorance about the HIV serology of the client attended. The invisibility of the virus and the symptoms, in the case of infection, is a proven fact, but the concern still remains with those known to be positive. Despite the objective, clinical and laboratorial distinction, between HIV infection and the AIDS disease, which is insistently reinforced by public agencies, the interviewees still have representations about the appearance of affected people that are presented in the neglect of standard precautions and in the postures of projection in relation to other workers in the services.
It can be affirmed that the results encountered point to representations not only of the order of scientific knowledge, but psychosocially constructed and integrated by the workers of the two primary healthcare services, the scenarios of the study. This allows the identification of the fragility of the current belief that the professional lives of health workers are anchored only in science, as many would like to believe. These results cannot be generalized, but add knowledge about ways of dealing with HIV/ AIDS infection, specifically those used by health professionals in their quotidian work. The findings show the importance of frequent in-service training and the creation, for example, of conversation groups among the professionals, so that there is exchange and clarification of doubts that provide fractures of stereotypes translated into prejudices and even incorrect attitudes that undermine the work process in primary care.

\section{References}

1. Ribeiro EJG, Shimizu HE. Acidentes de trabalho com trabalhadores de enfermagem. Rev Bras Enferm. 2007 setembro/ outubro; 60(5):534-40.

2. Grmek M. Les maladies à I'aube de la civilisation occidentale. Paris: Editions Payot \& Rivages; 1994.

3. Almeida CAF, Benatti MCC. Exposições ocupacionais por fluidos corpóreos entre trabalhadores da saúde e sua adesão à quimioprofilaxia. Rev Esc Enferm USP. 2007; 41(1):120-6.

4. Reis RK, Gir E. Dificuldades enfrentadas pelos parceiros sorodiscordantes ao HIV na manutenção do sexo seguro. Rev. Latino-Am. Enfermagem. 2005; 13(1):32-7.

5. Giami A, Veil C. Enfermeiras frente a aids: representações e condutas, permanências e mudamças. Canoas: Ulbra; 1997.

6. Moura EL, Praça NS. Transmissão vertical do HIV: expectativas e ações da gestante soropositiva. Rev. Latino-Am. Enfermagem. 2006; 14(3):405-13.

7. Moscovici S. Representações Sociais: Investigações em psicologia social. Petrópolis: Vozes; 2004.

8. Démazière $D$, Dubar $C$. Analyser les entretiens biographiques, I'exemple de récits d'insertion. Paris: Nathan; 1997.

9. Marques SC, Oliveira DC, Gomes AMT. AIDS e representações sociais: uma análise comparativa entre subgrupos de trabalhadores. Psicol Teoria e Prática. 2004; (ed especial):91-104.
10. Vieira KFL, Amaral ACG, Saldanha AAW. A vulnerabilidade à AIDS a partir das representações sociais de adolescentes. Anais da Jornada Internacional e Conferência Brasileira sobre Representações Sociais; 2007 11-20; Brasília; Brasil; 2007.

11. Ministério da Saúde (BR). Conselho Nacional de Saúde. Manual operacional para comitês de ética em pesquisa. Brasília (DF): Ministério da Saúde; 2002.

12. Chiodi MB, Marziale MHP, Robazzi MLCC. Acidentes de trabalho com material biológico entre trabalhadores de unidades de saúde pública. Rev. Latino-Am. Enfermagem. 2007; 15(4):632-8.

13. Reis RK, Gir E. Vulnerabilidade ao HIV/AIDS e a prevenção da transmissão sexual entre casais sorodiscordantes. Rev Esc Enferm USP. 2009; 43(3):662-9.

14. Paillard B. Le sida et La mort repoussante. Commun Peurs. 1993; 57:87-99.

15. Discacciati JAC, Neves AD, Pordeus IA. Aids e controle de infecção cruzada na prática odontológica: percepção e atitudes dos pacientes. Rev Odontol Univ São Paulo. 1999; 13(1):75-82.

16. Ministério da Saúde (BR). Portaria 1.679 de 19 de setembro de 2002 - Dispõe sobre a estruturação da Rede Nacional de Atenção Integral à Saúde do Trabalhador no SUS e dá outras providências. Brasília (DF): Ministério da Saúde; 2002.

17. Brasileiro M, Freitas MIF. Representações sociais sobre aids de pessoas acima de 50 anos de idade, infectadas pelo HIV. Rev. Latino-Am. Enfermagem. 2006; 14(5):789-95.

18. Le Breton D. Conduites à risque. Paris: PUF; 2004.

Received: Jun. $19^{\text {th }} 2009$

Accepted: Apr. $27^{\text {th }} 2010$ 